\title{
The Role of Children's Games in Shaping the Character of Group Communities in Japan
}

\author{
Lina Rosliana*, Arsi Widiandari and Fithyani Anwar \\ Japanese Department, Faculty of Humanities, Diponegoro University, Indonesia
}

\begin{abstract}
Children and games are difficult to separate. In playing the games, a child can hone many things, such as how to make friends, understanding the value of loyal friends, enthusiasm, the feeling of never give up, how to keep trying, tolerance towards others, and much more. By playing, especially in games that involve groups, a child will get the experience that will have a major influence on the formation of character and growth and development. Japanese society is known as a group society. The involvement of a person in a group is one of the ways on how to be a part of a community group. The pride of being a member of a community group is shown by the role and obligation of someone who is included in a group to realize the group's goals together. Of course, the importance of group awareness is not taught briefly but is something that has been accustomed since early childhood. This research will discuss the meaning of games made by children in Japan that form the character of the group society.
\end{abstract}

\section{Introduction}

\subsection{Japanese Society}

\subsubsection{Concept of Group Society}

Japanese society is known as a group society. This concept was discussed in a book written by Chie Nakane [1] entitled Japanese Society, which said that in all activities, Japanese people consider themselves to be part of a group. For example, the Japanese will introduce themselves by first mentioning their affiliation or place of work then followed by their name. Japanese society views that the workplace is not only seen as a place for someone to work but also as a place where a person belongs to a group of people.

As a group society, one must know the limits of uchi-soto from group life [2]. An employee from company A will regard the people involved in company A as their uchi, and consider the people in other companies as their soto. Group life in society, especially those that are tied to companies, has an added value for Japanese society, that is by feeling attached

\footnotetext{
* Corresponding author: linarosliana@lecturer.undip.ac.id.
} 
to groups, pride as part of a group, especially if the company in question is large. Awareness of the group will then lead to group orientation.

According to Kawamoto in Madubrangti [3], group orientation is a Japanese framework for group work based on a high awareness of group interests in the social life of the community which is bound by collaborative life in a unified group or community life.

The Japanese will try to carry out their role in the group by trying to follow the rules and carry out their duties and obligations. This group orientation action has emerged since traditional farming communities, which during this time, each farmer group has their respective duties and responsibilities that they will try to complement each other and realize the ultimate goal of the group.

The concept of group society is an embodiment of the IE system in traditional Japanese society. IE word has two meanings, that is as a house and a family system that is viewed as patriarchal. According to Chie Nakane, IE in the second sense is an embodiment of Japanese culture that does not exist in any country in the world [1] . Although this system has been abolished, it has influenced all aspects of Japanese life such as marriage, the economic system, and so on. This is consistent with the opinion expressed by Yanagita Kunio who said that "Japanese people from generation to generation treat IE as a mechanism for the desires of the ancestors to prosper, and this desire is conveyed to posterity. Then, with a relationship with their ancestors, and by making IE a home, IE also functions as a liaison between the Japanese and their country."

According to Madubrangti, in its history, the IE system played a role in making Japan a country as a single-family unit consisting of several smaller family units. In one family unit, each family member carries out the duties and obligations that govern the survival of its members [3].

\subsubsection{Previous Study}

Lois Peak in a journal entitled Learning to Become a Part of the Group: The Japanese Child's Transition to Preschool Life, argues that when compared to families, schools have a greater role in the process of group character formation. This research uses interview methods which are conducted to parents of students, as well as school teachers. The object of this study is to examine students who are still in the pre-school stage, specifically to find out the difficulties and challenges experienced by students and those around them in the transition from home or family environment into part of a group.

Diah Madubrangti, in her dissertation entitled "Makna Undoukai sebagai Kegiatan Kompetitif bagi Pembentukan Kepribadian Anak melalui Pendidikan Sekolah di Jepang" (The Meaning of Undoukai as a Competitive Activity for the Formation of Child Personality through School Education in Japan) revealed that the formation of a child's personality can be trained in a fun and healthy way through undoukai activities. In these activities, children will learn about working hard, trying hard, doing the best, and things that encourage them to be more competitive.

\subsection{Children's Games in Japan}

The types of games will affect the character and thinking of children. In Japanese society, there are a variety of children's games that can reflect the times, technology, social character, and values of life. This research will discuss the development of children's games in Japan from time to time, the types, and functions of the children's games. 


\title{
2 Method
}

This research is a descriptive qualitative research. Researchers tried to describe the role of children's games in shaping group communities society in Japan. This research model is to raise specific things, which only focuses on children's games by describing the data to represent the phenomenon in depth. The research stages include data collection, classification, and analysis.

\section{Results and Discussion}

\author{
Nawatobi (Jump Rope)
}

Nawatobi is a game that is played by groups. It can be played with large or small groups. The game is commonly played outdoors with a rope. In this game, it takes good cooperation between fellow participants.

This game requires two people in charge of holding each end of the rope, and the other game participants are tasked to jump when the rope is being swung. A participant who fails to jump will replace the rope holder. This game trains children to be able to work together with other children in one group so that they can jump together.

Hanetsuki (Japanese-style badminton)

Hanetsuki is interpreted as "tapping feathers". This game is a traditional game that emerged since Muromachi era (1338 - 1573). People in those days played it in the winter to celebrate and welcome the new year. On the bat, commonly given a traditional ornament with a gold or silver color, especially during the Genroku era (1688 - 1704) in the Edo period. This game is played by girls and in two ways, namely Oibane and Tsukibane.

Oibane involves two players, where they had to take turns hitting the shuttlecock toward other players during the game. Meanwhile, Tsukibane is done alone, which the player has to hit the shuttlecock upwards as much as possible.

\section{Karuta}

Originating from Portuguese, who entered Japan through missionaries in the $16^{\text {th }}$ century. This card game is played by three or more people. According to Bull [4], in his journal entitled "Karuta: Sport or Culture?", Karuta was originally played by the Bushi (the highest caste in the Shinokosho system), but as the time went by, this game could be played by all groups of people.

This game is commonly played in the Washitsu room (Japanese-style room) by aligning all cards on the base (commonly Tatami) so that each player can easily see the cards. Players will try as fast as possible to pick a matching card, the card drawn is a card that contains the 
Kana script (picture) or continued Tanka (Japanese poetry) that is read. The participant with the highest number of cards is the winner of Karuta.

\section{Takoage (Kite)}

When playing a kite, parents teach children how to work together with others. Every child in kite laying has an important role, so that the nature of mutual need and mutual respect are embedded.

\section{Otedama}

Otedama was originally taught by parents to girls to teach children to sew. First of all, children will make a ball out of fabric by cutting and sewing the fabric themselves to form a ball. This game also teaches the agility of children in throwing and catching the ball.

\section{Hana Ichi Monme}

This game is played by two groups (each group commonly consists of 4 children). Each group will face, hold hands, and sing songs to each other. It starts with the rock-paper-scissors game to determine which team wins. The winning team in rock-paper-scissors will start singing the song followed by the losing team.

The lyrics of the song illustrate that each team wants one of the children to be taken into their group. After each team mentions the name of the desired child, the child whose name is called will do the rock-paper-scissors game. Children who lose must join the opposing group. This game continues until one of the groups has no more members.

\section{References}

1. Chie Nakane. Japanese Society. California: University of California Press, i-ii (1972)

2. Hyoe Murakami (ed). Guides to Japanese Culture. Tokyo: Japan Culture Institute (1997)

3. Diah Madubrangti. Makna Undoukai sebagai Kegiatan Kompetitif bagi Pembentukan Kepribadian Anak Melalui Pendidikan Sekolah di Jepang. Disertasi Kajian Wilayah Jepang Program Pascasarjana, Depok: Universitas Indonesia, 41 (2004)

4. David Bull. Karuta: Sport or Culture?. Japan Quarterly; Jan/Mar 1996; 43, 1; Research Library (1996) 